\title{
Dollar Dilemmas During the Downturn: A Financial Crossroads for College Sports
}

\author{
Andrew Zimbalist \\ Smith College
}

\begin{abstract}
This paper undertakes three challenging tasks. First, I attempt to lay out the dimensions of the current financial crisis that confronts intercollegiate athletics. Second, I propose three reforms that I believe, if enacted, would go a long way toward ameliorating the financial situation and also bring the practice of college sports more in line ethically with its purported mission. Third, I assess the prospects of these reforms being carried out, given the history of failed reform efforts in the past.
\end{abstract}

\section{The Financial Landscape}

Although there is a group of economists who argue that big-time college athletics departments run a surplus in reality, I am not in that group. Based on figures I have seen from the NCAA, from the EADA, from individual conferences and individual schools, I believe that all but a handful of schools' athletic departments run a deficit when properly accounted. Indeed, the late NCAA President Myles Brand stated on a number of occasions that only a half dozen schools run a true surplus on a consistent basis. Similar appraisals were made by his predecessors Ced Dempsey and Dick Schultz.

Consider the NCAA figures. According to its 2009 report for the 2007-08 year, out of 119 schools in the Football Bowl Subdivision (FBS) of Division I (formerly DIA), only 25 athletic departments generated a net operating surplus. ${ }^{1}$ These schools had an average reported operating surplus of $\$ 3.87$ million. The remaining 94 schools generated an athletic operating deficit, which, among them, averaged $\$ 9.87$ million. For the entire 119 schools, the median operating deficit was $\$ 8.1$ million (Fulks, 2009). ${ }^{2}$

The NCAA does not release financial figures for individual colleges and other than incomplete and irregular data reported to the U.S. Department of Education in the annual EADA reports and the release of program financials in public record documents, the public rarely gets a candid look at the bottom line for particular athletic departments. However, budgetary information of the athletic department at the University of California, Berkeley was made public in early November 2009. According to the information sheet, the school's athletic department was a 
net loser of between $\$ 7.4$ million and \$13.5 million every year between 2003-04 and 2009-10, costing the university a total of $\$ 78.1$ million over this seven-year period. Furthermore, these losses do not include the annual debt service on two new capital projects (the $\$ 321$ million renovation of Memorial Stadium and the $\$ 136$ million Student Athlete High Performance Center; access to the latter will restricted to the school's 450 student-athletes). ${ }^{3}$

It is important to point out that the summary NCAA figures can be misleading. Although Jim Isch, Dan Fulks and others have made heroic efforts to standardize and rationalize intercollegiate athletic accounting and reporting practices, there remains a great deal to be done. I won't go into all the gory details, but a few salient issues should be mentioned. First, schools do not regularly report capital expenses and those that do, do so unevenly and incompletely. As Jonathan and Peter Orszag have demonstrated in their 2005 study for the NCAA, capital costs, properly reckoned, can be appreciable. Based on facility replacement cost, the Orszags estimated an annual capital cost in DIA athletic departments of \$24 million, just a few million dollars below the average annual operating costs of DIA intercollegiate athletics departments at the time (Orszag and Orszag, 2005). Alternatively, NCAA data reveals that the top decile of FBS programs paid out a median of $\$ 6.56$ million of debt service on a debt of $\$ 98.1$ million in 2007-08. This debt service is generally paid outside the athletics department (e.g., by the university or the state) and does not appear as an expense item in the athletics department budget. Thus, if capital costs were fully and properly accounted, it is safe to assume that these reported deficits would balloon significantly.

Second, it is not clear to what extent indirect costs are included in the financial reports of athletic departments. Although NCAA reporting forms have been modified to call for the inclusion of many indirect costs, the instructions are often not explicit or detailed. Some schools may include, for instance, estimates of the costs for the time university administrators spend on athletics, while others may not. The same is true for a pro rata share of the administrative building capital and operating costs. And so on.

Third, schools follow varying practices regarding accounting for athletic grants-in-aid (GIAs). The basic conundrum here is that some schools count the value of the GIA at full tuition and room and board, when the marginal tuition cost may be negligible. If a school has empty beds in its dormitories, the marginal cost of filling such a bed with an athlete is trivial. If that athlete attends classes, there is no additional instructional cost, and the athlete is sleeping in a bed that would otherwise be empty. The athletics department might record the operating cost associated with this athlete's GIA at its full nominal value, say $\$ 35,000$, while the actual incremental cost to the school might be closer to $\$ 5,000$ or $\$ 10,000 .{ }^{4}$ To the extent that this experience applies at certain state universities, athletics costs and operating deficits are overstated.

Fourth, where generated revenue is used, the exclusion of student fees may understate the market value created from student attendance at games. Practices at different schools vary widely, regarding the size and use of the student fee and whether students are given free tickets or sold subsidized tickets to sporting contests.

To be sure, when all adjustments are made, it seems that true athletics deficits would be considerably larger than reported deficits; that is, the omitted costs appear to significantly exceed the overstated costs. The reasons for this are manifold. Fore- 
most among them is that athletic departments are large, not-for-profit bureaucracies. Rather than following a bottom-line imperative to boost quarterly profits and stock prices, they tend to follow the bureaucratic imperative to grow at any cost and to do anything they can to win. Actual FBS budgets, then, run in substantial deficit and the gap between expenses and revenues is growing at the vast majority of schools.

What about the often heard responses that the value of big-time college athletics lies in its ability to (a) increase student applications and (b) generate increases in donations to the university general fund?

One hears frequent claims that a successful football or basketball team increases student applications ${ }^{5}$ and that this, in turn, enables a school to be more selective and increase the quality of its student body. While it appears to generally be the case that big-time athletics success may modestly increase applications, it is less clear that that this increase leads to better students. The reason is that the large majority of new applications tend to be from students at the bottom of the academic performance ladder. The econometric scholarship on the effect on student quality is somewhat contradictory. Nonetheless, the bulk of the extant econometric research suggests that any such effect is either nonexistent or small and short-lived (Pope and Pope, 2009). ${ }^{6}$

An important related point is that many large state universities do not fill all their beds. If athletics success increases applications, even if the school is not able to be more selective, it may be able to increase enrollment and, hence, revenue. In this way, athletics success may provide a financial benefit.

The literature is also somewhat uneven and inconclusive on the question of athletics success promoting donations to a school's general fund. Undoubtedly, there are some schools, particularly those experiencing a meteoric rise from athletics oblivion to national prominence, where success does lead boosters, alumnae, and state legislators to open their wallets. In general, however, to the extent that some studies find a positive and significant effect in panel data studies, it is very modest in magnitude. Many studies find no significant effect. ${ }^{7}$ While it is likely that athletics success will lead to increased giving to the athletics department or its foundation, giving to the general fund is more uncertain. Indeed, there is evidence that increased donations to athletics have cannibalized donations to the general fund. For instance, between 1998 and 2003, a period when overall giving to universities was flat, athletics departments received an increased share of total gifts-from $14.7 \%$ to $26 \%$. $^{8}$

Both in the case of increased applications and increased donations, it is necessary to remember that a positive and significant coefficient implies that the relationship goes in both directions. That is, if improved athletics performance generates increased applications or donations, then deteriorated performance will engender decreases in applications and donations. In the end, the average win percentage is .500, and one college's gain will be another's loss. A particular college will also find its gain one year, may be its loss the next if it cannot sustain its athletics success. Moreover, the quest for victory often leads schools to transgress NCAA rules. Investigations and scandals may ensue and their negative impact may last for years. ${ }^{9}$

From the perspective of an individual university, even if a clear link could be established between athletics success and increased applications or donations, there is an opportunity cost in investing in improved athletics performance. If a 
university's goal is increased applications or donations, then investing in athletics must be compared with investing in the best alternative. Only if athletics investment yields higher returns than, say, investing in excellent faculty, science laboratories or growing the development office would it make economic sense to increase spending on athletics. Further, competition among schools to capture the expected gains from athletics success would eventually eliminate those gains, as schools spent more and more money on recruitment, facilities, coaches' salaries and the like, while the fact remained that only ten schools can be ranked in the top ten. ${ }^{10}$

The final pattern to observe is that the situation appears to be growing worse in the aggregate and also distributionally. A 2009 Knight Commission study reported that in the FBS athletic spending has been growing at four times the rate of the general educational budget (Weiner, 2009). The 2009 Revenues and Expenses Report of the NCAA found that the median net operating deficit for FBS athletic programs grew from $\$ 5.57$ million in fiscal year 2005 to $\$ 8.09$ million in fiscal 2008, a 45.4\% increase over the three years (Fulks, 2009, p. 19).

As the aggregate situation deteriorates, the top schools in the leading conferences continue to be able to generate operating surpluses. Meanwhile, the condition for all the other programs grows worse and worse. The $119 \mathrm{FBS}$ schools constitute the upper echelon of athletic programs among the over 1200 colleges belonging to the NCAA. In 2005-06, the 19 programs that reported an operating surplus (based on generated revenue) had a median surplus of $\$ 4.3$ million, while the 100 programs with an operating deficit reported a median deficit of $\$ 8.9$; that is, the gap between these two groups of have and have-nots was $\$ 13.2$ million. This gap had grown by $\$ 2$ million since 2003-04 (Brown, 2008).

If the $119 \mathrm{FBS}$ athletic programs are divided into deciles, the following pattern emerges for the 2006-07 academic year. As depicted in Table 1, the median revenue of programs in the lowest decile (ranked by revenue) was $\$ 13.1$ million, while that of the highest decile was $\$ 89.1$ million, almost seven times higher than the lowest ten percent of programs. It is important to emphasize that these figures are for total revenue; that is, they include both revenues generated by the athletics department and allocated revenues (transfers from the university and the public sector). If only generated revenues were considered, the bottom decile would have a median of $\$ 5.4$ million, while the top decile would have a median of $\$ 89.0$ million-for a top-to-bottom ratio of over $16-1 .{ }^{11}$ Only the top decile reports a surplus without institutional subsidies, and, again, these figures exclude capital expenses.

Despite the clear superiority in the performance of the top decile, when capital and indirect expenses are included in the balance, it is probable that not even all the top ten percent of revenue programs generate a surplus in a typical year.

The economic challenges are greater still if one acknowledges that (a) the NCAA's rules restrict an athlete's GIA in most cases to being \$2,500 or more below the full cost of attending college, (b) the NCAA and its member schools in Division I face a serious antitrust and unjust enrichment challenge over their appropriation of athletes' publicity rights, ${ }^{13}$ and (c) despite impressive progress, women still lag well behind men in athletics participation and resource allocation. Across the NCAA in 2007-08, women were $42.6 \%$ of all athletes (this share was basically stagnant during the two terms of the Bush administration), but approximately $55 \%$ of all undergraduate students. 
Table 1 FBS Revenue and Expenditure Distribution Median By Decile, 2006-07 ${ }^{12}$

\begin{tabular}{lccc}
\hline Deciles & $\begin{array}{c}\text { Grand Total } \\
\text { Expenditures }\end{array}$ & Grand Total Revenue & $\begin{array}{c}\text { Grand Total } \\
\text { Generated Revenue }\end{array}$ \\
\hline 1 & $\$ 14,143,000$ & $\$ 13,135,000$ & $\$ 5,351,000$ \\
2 & $\$ 19,705,000$ & $\$ 19,954,000$ & $\$ 7,925,000$ \\
3 & $\$ 23,417,000$ & $\$ 23,390,000$ & $\$ 11,609,000$ \\
4 & $\$ 27,955,000$ & $\$ 27,098,000$ & $\$ 15,062,000$ \\
5 & $\$ 33,783,000$ & $\$ 33,783,000$ & $\$ 24,652,000$ \\
6 & $\$ 42,967,000$ & $\$ 44,944,000$ & $\$ 35,283,000$ \\
7 & $\$ 52,255,000$ & $\$ 53,719,000$ & $\$ 47,756,000$ \\
8 & $\$ 57,987,000$ & $\$ 60,967,000$ & $\$ 58,167,000$ \\
9 & $\$ 68,377,000$ & $\$ 72,256,000$ & $\$ 70,358,000$ \\
10 & $\$ 83,135,000$ & $\$ 89,080,000$ & $\$ 89,028,000$ \\
\hline
\end{tabular}

The financial landscape, then, is marked by widespread and growing deficits, as well as a deepening divide between the have and have not schools. The 2008-09 global financial crisis and economic downtown have only exacerbated the already untenable situation. Further, the concomitant crisis in the financing of higher education and increasing questions about the future viability of the basic economic model of U.S. universities shine yet a brighter light on the growing deficits in intercollegiate athletics.

There is a saying of growing currency that no good recession should go to waste. Recessions are a time to curb excesses and waste, and many athletic programs have been shaken out of their longstanding complacency and growing extravagance into a cost cutting mode. So some positive steps have been taken by certain schools and conferences ${ }^{14}$ but they are all incremental and insufficient given the magnitude of the problem.

Even the Athletic Directors of Division I have recognized that business as usual is not sustainable and they have called for a series of reforms, such as cutting back on glossy media guides, shortening the playing season in nonrevenue sports (this is likely to be in violation of Title IX), reducing traveling squads, restricting off-season practices, eliminating some sports, and ending the common practice of lodging teams at local hotels before home games. There is also the danger, however, that, as in the past, some reforms will spring loopholes. For instance, several years ago the NCAA passed a regulation that prevented student-athletes from being segregated in separate housing. Schools began to put student-athletes in special married graduate student housing complexes, which, in effect, had the same impact as segregated housing. If student-athletes are prohibited from staying in local hotels, the response may be to build more luxurious "graduate student" housing. Notably, the Division I athletic directors stayed away from recommending more substantial reforms; thus, while the AD's plan may slow the pace of ballooning deficits, it is unlikely to reverse the tide. ${ }^{15}$

In the next section, I suggest some deeper measures that could make more significant contributions to achieving fiscal sanity and greater financial balance in big-time intercollegiate athletics. 


\section{Policy Reforms for Fiscal Solvency}

Unless they decide to opt out of competition, schools cannot solve the budgetary crisis on their own. Competitive forces compel ADs to spend on coaches, facilities and amenities. The only reasonable path to reform is through collective action. The problem is certain types of collective action by the NCAA can be construed to be in violation of Section 1 of the Sherman Antitrust Act.

\section{Seek a Partial Antitrust Exemption to Regulate Coaches' Salaries}

Examples of waste abound in Division I athletics, but perhaps the most egregious is the salaries paid to head football and men's basketball coaches-which often exceed the salaries of the university's president by a factor of 5-10. ${ }^{16}$ Today, there are over 100 college football coaches with compensation packages exceeding \$1 million; there are more than a dozen exceeding $\$ 3$ million, and several exceed $\$ 4$ or $\$ 5$ million in monetary compensation alone. ${ }^{17}$

Men's basketball coaches are not far behind: in 2005-06, the coaches of the 65 Division I teams in the NCAA tournament had an average maximum compensation of $\$ 959,486$, with the top-paid coach earning a guaranteed salary of $\$ 2.1$ million and a maximum salary of $\$ 3.4$ million. ${ }^{18}$ The salaries have continued to grow. For instance, in 2009, the University of Kentucky agreed to pay John Calipari a guaranteed $\$ 31.65$ million (plus incentives) over eight years. These figures exclude bonuses as well as extensive perquisites, including free use of cars, housing subsidies, country club memberships, private jet service, exceptionally generous severance packages, and more. The coaches also have handsome opportunities to earn outside income via apparel or sneaker endorsements, the lecture circuit and book contracts.

Not surprisingly, assistant coaches have also experienced an explosion in their pay packages in recent years. For instance, Tennessee lured its new defensive coordinator in 2009 , Monte Kiffin, with a $\$ 1.2$ million salary, a $\$ 300,000$ bonus for staying through the end of the regular season ${ }^{19}$, up to another $\$ 100,000$ in incentives and the use of two cars. The average salary for the nine assistant football coaches at Tennessee was $\$ 369,000$ in 2009. USA Today identified over 100 assistant coaches in the FBS who receive over $\$ 250,000$ in base compensation. Bob Stoops, Oklahoma's head football coach, is guaranteed \$4.3 million in 2009 and his nine assistants will total nearly $\$ 2.5$ million before bonuses. Alabama and LSU also boast $\$ 6$ million-plus staffs (Wieberg, 2009).

Back in 1924, Centenary College in Shreveport, Louisiana, the nation's first liberal arts college west of the Mississippi, was denied accreditation by the Southern Association of Colleges and Schools because the school placed an "undue emphasis on athletics." The primary evidence of Centenary's misplaced priorities by the Southern Association was that the college paid its football coach more than it paid its college president. The next year the football coach was gone and the college gained accreditation (Johnson, 2008).

More recently, the legendary head football coach at the University of Alabama (1958-1982), Bear Bryant, adhered to a firm policy of always keeping his salary $\$ 1$ below that of the school president. Bryant believed that it was symbolically 
important for the university president to be paid more than the head football coach (Barra, 2005).

Defenders of the multimillion dollar head coaches' salaries are wont to repeat the mantra: "Coaches' compensation packages are driven by market forces." Fair enough, but what drives the market forces? It is clear that the market for coaches is sustained by several artificial factors: (a) there is no compensation paid to the athletes; (b) intercollegiate sports benefit from substantial tax privileges; (c) there are no shareholders demanding dividend distributions or higher profits to bolster stock prices; (d) athletic departments are nourished by university and state-wide financial support; and, (e) coaches' salaries are negotiated by athletic directors whose own worth rises with the salaries of their employees.

In a normal competitive market, college football coaches would not be getting compensated almost at the same level as NFL coaches. The top 32 college football programs generate revenues in the \$40-70 million range; the average NFL team generates around $\$ 230$ million.

The central point is that if the NCAA placed, say, a $\$ 400,000$ limit on coaches' compensation packages, it would not affect the quality of coaching or the level of intercollegiate competition one iota. This is because the next best alternative for top college coaches (the reservation wage) is likely to be well below this level. Anything above the reservation wage is what economists call economic rent.

It is clear that coaches are being paid in part for the value produced by the athletes they recruit, who do not get paid. That is, the marginal revenue product of the star players accrues largely to the head coach, rather than to the players. This is reason enough to cap coaches' salaries. It is more reason because much of the work of recruiting is done by assistant coaches and much of the attraction a school has to a player has to do with the school's conference, its reputation and its facilities, all factors independent of the head coach.

Finally, coaches' compensation does not appear to be significantly correlated with team performance. While one could make the argument that certain coaches have turned around the fortunes of a team, taking it from oblivion to prominence over the course of a few years, and, therefore, they have added sufficiently to the school's revenues to justify their high salaries, such coaches are few and far between. Even in these cases, it is the athletes who are producing the winning teams and their compensation is being suppressed. In the end, only ten schools can be in the top ten rankings and the average win percentage of all schools will always be .500 . Nonetheless, virtually every head football coach in the FBS earns over \$1 million. This obviously includes coaches of perennially losing teams.

I collected data on compensation levels of head coaches in Division I men's basketball and Division IA football and compared these levels to different measurements of team performance. I ran multiple regressions and panel regressions to explore the extent of correlation between coaches' salaries and team performance with different lag structures. The regression results do not suggest that the more highly paid coaches are associated with more successful teams in current years; rather, they suggest that higher salaries are positively correlated with a school's historical success. That is, team success appears to be correlated with longstanding institutional factors rather than the performance of the current coach (Zimbalist, 2010b). ${ }^{20}$

Thus, there are strong economic and ethical reasons to attempt to cap coaches' salaries. ${ }^{21}$ Doing so would save millions of dollars for the typical FBS program. 


\section{Reduce the Number of Football Scholarships}

Another example of extravagance is the size of FBS football teams. DIA football teams do not need 85 scholarships. Sixty would do fine. ${ }^{22}$ NFL teams have a maximum active roster of 45 , plus a maximum inactive roster of 8 additional players. ${ }^{23}$ The average FBS team has 32 walk-ons plus 85 scholarship players (NCAA, 2008, p. 27). If football scholarships were cut to 60 , the average college would probably save over $\$ 1$ million annually ${ }^{24}$ _easily enough to finance an average FBS soccer team plus an average FBS golf team, or an FBS tennis team plus gymnastics team, and have several hundred thousand dollars left over (Fulks, 2009, p. 37). Even assuming the number of walk-ons would not increase with the lower scholarship limit, the average squad size would still be 92 .

\section{Introduce an FBS Playoff System}

In 88 other varsity sports and divisions, the NCAA has organized playoff competitions for national championships. In FCS, Division II and Division III football there are playoffs, some with 16 teams. Only in FBS football does the NCAA not organize a national championship playoff. Instead, the NCAA has allowed its six equity conferences organize their own putative national championship that involves no playoff, but instead substitutes its own highly flawed, unfair and anticompetitive BCS five-game bowl system.

First, the BCS system is flawed because the method it uses to select its ten participating teams, including its top two teams for the national championship, that includes an inadequately and improperly specified set of criteria in its computer algorithms and a coaches' survey that involves both a conflict of interest and unbalanced information (Zimbalist, 2010a). ${ }^{25}$ Ultimately, there is always a dispute about the selected teams and always a doubt about whether the true national champion has been crowned. The fact of the matter is that no system is perfect, but there is a U.S. sporting culture that embraces a playoff system. In a playoff, the teams compete against each other on the field to see who is better. Playoffs prevail in all other NCAA championships and throughout professional sports. The championship is not left up to a largely arbitrary numerical and subjective system.

Second, the BCS system is unfair because it distributes its slots for BCS games as well as the revenue from these games prejudicially. The six equity conferences that created and control the BCS system each have their conference champions receive an automatic berth to one of the five BCS bowls. In 2008-09, each of the six automatic qualifying (AQ) conferences received a guaranteed \$18.6 million. The five non-AQ conferences in the FBS can earn an automatic berth if either: (a) the team ranks in the top 12 of the final BCS standings, or (b) the team ranks in the top 16 of the final BCS standings and its ranking is higher than that of the champion of one of the BCS conferences. However, no more than one team from a non-AQ conference can earn an automatic berth in any given year; thus, there is no automatic berth for a second non-AQ team. ${ }^{26}$ If a non-AQ team does compete in a BCS bowl, its conference received only $\$ 9.8$ million in 2008-09, or just little over half of what an AQ conference received.

Overall, during the first 12 years of the BCS system, there have been 98 appearances by BCS conference teams and only 6 appearances by non-BCS conference teams, five of which occurred during the last four years. A non-AQ team has never 
been selected to participate in the national championship game, and, given the parameters in the selection process, it is unlikely in the extreme that one ever will be selected. During the three-year period 2007-09, total payouts from the BCS bowls amounted to $\$ 410.1$ million, of which $\$ 355.1$ million (or $86.6 \%$ ) went to BCS conferences. ${ }^{27}$ The effect of this lopsided selection and distribution process is to calcify the FBS into a caste system.

Third, the BCS system is anticompetitive because it restricts output (quantitatively and qualitatively) and reduces consumer welfare. Currently, there are only five BCS bowl games, and, of these, only one is relevant to deciding the putative national champion. In an eight-team playoff, there would be seven games and all seven would be relevant to deciding the national champion. All 120 schools in the FBS would be equally eligible for selection and a broader cross-section of the country would be interested in the results. It is not imaginable that the television contracts would grow by anything less than $100 \%$ under the circumstance of an eight-team playoff. ${ }^{28}$

Over the years, the BCS has offered a series of justifications for its system. I discuss these at length elsewhere (Zimbalist, 2010a). In my view, these rationales are patently self-serving and unconvincing.

In addition to creating a fairer and more revenue-enhancing system, an FBS playoff would have one other significant salutary impact. The revenue from an NCAA-organized FBS playoff would be distributed more equally across the 120 schools in the FBS, and it would share more of the revenue with the other schools in the rest of Division I, as well as share $4.37 \%$ with Division II and $3.18 \%$ with Division III. Not only would this help narrow the growing divide between rich and poor athletic programs, but it would blunt the incentives to chase football success. With a smaller payoff, schools will have less incentive to spend for coaches, for recruiting, for facilities, etc., and the arms' race should be slowed down.

\section{The Prospects for Implementing Structural Reform}

I have no illusions that deep reform will come easily. People have been trying to thwart the juggernaut of commercialization in college sports since the 1890s. What is different now is that the financial stakes have multiplied, the athletics bottom line has become acutely more problematic, and the traditional university model is suffering. The necessity for incremental change has already been recognized by the Division I Athletic Directors. These sensibilities are only heightened by the difficult macroeconomic environment.

College presidents are expressing more interest in serious reform measures and a 2009 survey of FBS presidents sponsored by the Knight Commission identified astronomical coaches' salaries as college sports most urgent financial problem. ${ }^{29}$ Members of Congress and President Obama have manifested concern over the absence of a playoff system in the FBS.

Whether this energy can be harnessed and mobilized into an effective reform movement remains to be seen. The same college presidents who identified high coaches' salaries as financial enemy number one evinced pessimism about being able to do anything about the problem. Most appear to be skeptical about seeking an antitrust exemption from the U.S. Congress. There is an unspecified fear that if colleges invite government into their business, then Congress will seek greater control and regulation over it. 
But why would some intervention by the government be so bad? Since 1995, the NCAA has faced many major legal challenges, beginning with the restrictive earnings coaches suit, and continuing with the N.I.T. antitrust case against the NCAA's March Madness, the preseason tournament limitation rule case, the cost of attendance versus scholarship limit litigation brought by Jason White, the Ohio baseball player (Andrew Oliver) suit against the NCAA which prohibits the use of lawyers by players to discuss professional contracts, the Keller and O'Bannon cases over current and former college players' publicity rights. The NCAA has not fared well in most of these cases and, in my view, its prospects are not good in the last two. Most of these matters, even though some have reached costly settlement, have not been put to rest. The NCAA's hybrid model, combining elements of amateurism and professionalism, seems to engender legal ambiguity and invite litigation. The NCAA could use some help it seems and a bit of Congressional intervention may prove constructive.

That said, the U.S. Congress is already well aware of issues in college sports and has called numerous hearings to explore them. The U.S. government is deeply involved in matters concerning higher education and even in intercollegiate sports via programs such as Title IX and Pell Grants. The IRS has reevaluated its taxing policies with regard to donations for seating priorities and UBIT, as has the Congressional Budget Office. In short, the government does not need a discussion around a partial antitrust exemption for the NCAA to tempt it to become more intrusive. As renown journalist and former U.S. State Department official Hodding Carter III stated recently: if college sports wants government out of its business, then college sports should remove its snout from the government trough.

Another obstacle to reform is the NCAA itself. The Association, in essence, functions as a trade association for coaches, athletic directors and conference commissioners. The few college presidents who have become involved in NCAA committees often tend to be passionate sports fans and have little instinct to rock the boat. All presidents who serve on NCAA committees are expected to represent the interests of their conference. President Bernie Machen at the University of Florida was quoted in the Sports Business Journal as saying that the SEC would not allow him to be the conference representative because he believes there should be a more equitable distribution of BCS monies. ${ }^{30}$

The vast majority of presidents who do not serve on NCAA committees generally have abdicated responsibility for their sports programs to the ADs and, secondarily, to the provosts and faculty athletic representatives whom they appoint. The ADs and coaches have little motivation to reduce the number of football scholarships or to seek an antitrust exemption that might lead to the decimation of their salaries.

The representation on NCAA committees is heavily weighted toward Division I, and within Division I toward the FBS, and within the FBS toward the BCS or equity conferences. Given this power structure, it is understandable why the NCAA has not pushed for a football playoff in the FBS. What all this means is that momentum and pressure for reform will likely have to come from outside the Association.

The history of Title IX instructs us that this is possible. Further, it is becoming increasingly apparent that current patterns are not sustainable. Schools are cutting back some sports and eliminating others. A few rich programs at the top are thriving, some are just surviving, but the overwhelming majority of programs realize that business as usual is over. 
I think the reforms outlined above are possible politically. Their intent is to preserve and strengthen intercollegiate athletics by putting them on a sounder and more equitable financial footing. Whether they come to fruition will depend upon the organizational effort and skill that is put behind them. One thing is certain: if reform-minded university presidents and others give up before they begin, as many appear to have done in their answers to the Knight Commission survey, then no productive change will result.

\section{Notes}

1. Only 18 schools generated a net operating surplus over the five-year period 2003-04 through 2007-08. These figures do not include most or all of capital spending on the cost side, nor do they include all of the indirect costs associated with running the athletics program, among other problems.

2. For more analysis of the trends for athletic expenses to grow more rapidly than athletic revenues or university educational expenses, also see: Litan, Orszag \& Orszag, 2003; Orszag \& Orszag, 2005: and, Orszag \& Israel, 2009.

3. Information Sheet on Intercollegiate Athletics and Faculty Resolution, University of California, Berkeley, November 2009. Meanwhile, the Berkeley faculty senate, in the face of academic cuts, voted to end all subsidies to the school's athletics department. A month later, the faculty senate at the University of Texas issued a similar protest after the football coach's contract was renegotiated upward to exceed $\$ 5$ million annually.

4. If there are no empty beds, then there is an opportunity cost to giving an athlete a scholarship; namely, the place could have been occupied by a student paying the face value (or a portion thereof) of the school's tuition, room and board.

5. Such claims often begin with the invocation of the legendary Flutie effect, named for Doug Flutie's dramatic 1984 touchdown pass which lifted Boston College over the University of Miami. The Flutie effect, however, is chimerical. Boston College's application increases of $16 \%$ in 1984 and $12 \%$ in 1985 (not the 30-40\% often cited in media reports) were consistent with the underlying trend rate at the school (McDonald, 2003).

6. Pope and Pope (2009) review the literature and run additional tests. They find that certain types of athletics success appear to increase interest in a school from applicants with high, low and medium SAT scores; they do not find, however, that the initial interest translates into more applications or admits from the high SAT group. In the end, they conclude that the "summary data in Table 2 would suggest that athletically successful schools actually saw slightly slower long-run growth in applications and enrollments" (Pope \& Pope, p. 776). Frank (2004) reviews the literature as well and arrives at a similar conclusion. Also see, Zimbalist, 2001, ch. 7, and Orszag \& Orszag.

7. The 2009 study by Orszag and Israel for the NCAA, for instance, reached the following conclusions: "In our previous reports we found no evidence to establish a pattern, positive or negative, between athletic expenditures and academic quality.... Our updated results continue to show no consistent support for such a relationship.... In our previous reports, we found no consistent evidence for a relationship between operating expenditures on sports and alumni giving. Using data from 2004-07, ... we do not consider the observed statistical relationship between athletic expenditures and alumni giving to be robust enough to suggest a causal relationship." Orszag \& Israel, pp. 10-11. In addition, see Frank.

8. See Stinson \& Howard, 2007; and, Humphreys \& Mondello, 2007.

9. See, for instance, Rhoads \& Gerking, 2000.

10. This theoretical expectation is consistent with the empirical finds in Orszag and Israel, p. 6 , where they find that an additional dollar of athletics spending leads to an additional dollar of revenue, i.e., there is a zero net return to the spending. 
11. This growing divide occurs both across and within conferences. When it is within conferences, competitive balance of the on-field competition is threatened. Iowa State, Nebraska and Texas all play football in the Big 12 conference, one of the six BCS conferences. According to data from the most recent EADA reports, Iowa State's football revenue was \$17 million, while that of Nebraska was $\$ 49$ million and that of Texas was $\$ 73$ million. See http://ope.ed.gov/athletics.

12. Weiner, J. (2009).

13. See the O'Bannon and Keller lawsuits.

14. For a discussion of some of these measures and where they have been implemented, see, for one, Smith, 2009.

15. It may also be the case that some of the AD's proposed reforms, such as eliminating certain teams or restricting the number of scholarships, will provoke antitrust challenges from affected athletes. In this case, an antitrust exemption would be protection for the NCAA.

16. In a sample of 45 Division I public universities, Duke economist Charles Clotfelter found that between 1986 and 2007, the average compensation of full professors rose $30 \%$, while that of university presidents grew $100 \%$, that of head basketball coaches jumped $400 \%$ and that of head football coaches increased $500 \%$. (Clotfelter had full data on basketball salaries for 22 schools and on football salaries for 45.)

17. Pete Carroll's compensation at USC in $2009-10$ reportedly was $\$ 4.4$ million. Alabama's football coach Nick Saban had his \$4 million a year contract extended and enriched in 2009. The new contract, in addition to endless, handsome perquisites and a variety of bonuses, guarantees him $\$ 44$ million through 2018. Mack Brown, the football coach at the University of Texas, did Saban one better: signed later in 2009 Brown's new contract provides for a guaranteed $\$ 5$ million salary in 2010, with annual increases of $\$ 100,000$, through 2016.

18. The sources for these figures are discussed in the statistical section below.

19. As it turns out, Monte Kiffin did finish the regular season at Tennessee-but just barely. On January 12, 2010, he and his son (Lane Kiffin, the head coach) decided to leave Tennessee after one year to follow a better offer from USC, replacing Pete Carroll who had departed for the NFL's Seattle Seahawks amid various investigations around improprieties of the program at USC.

20. See Zimbalist, 2010b, forthcoming, for more details. Orszag \& Israel reach similar conclusions.

21. To be sure, as with any piece of legislation circumscribing the market, there will be efforts to avert the controls. That is, if compensation limits are imposed, schools will look for ways to indirectly remunerate coaches. The U.S. Congress need not concern itself with these details if it grants the NCAA a partial antitrust exemption; if the NCAA takes advantage of such an exemption, the Association will have to detail the regulation so as to minimize transgression. It would probably be unwise to apply a Bryant Rule, limiting coach's pay to that of the university president, because this will likely engender significant inflation in presidents' pay. An alternative would be to limit head coaches' pay to, say, $300 \%$ above that of the average salary of all assistant professors at the school or in the conference. There would also have to be a limit imposed on the value of all benefits and perquisites at, say, $40 \%$ of the compensation maximum, as well as a restriction on outside income, requiring most of it to be channeled through the university.

22. College coaches have protested that college football teams cannot be properly compared with professional teams. The latter, they say, can always call up reserves when players get injured, but college teams must have players on their rosters to replace the injured. First, NFL teams have a maximum of 16 players on reserve and practice squads to complement their 45 -men active rosters. Second, the NCAA Injury Surveillance System Summary reports that for the 2000-01 season, the serious-injury rate during games in football was 14.1 per 1000 exposures, while the rate in football practices was 1.6 per 1000. If we assume that 60 players enter a game and the team plays 13 games during the year (that is, including a postseason game), then the average total number 
of serious injuries (where a player is out sever or more days) from games is 11 per year. If on average each such player misses two games, then the average number of game-injured players is 1.69 per game. Performing a similar calculation for practice-injured players yields 1.48 per game for a combined average of 3.17 injured players per game. This hardly constitutes a justification for carrying 85 scholarship and 117 total players on an FBS team.

23. Teams are also allowed to carry up to 8 additional players on their practice squad.

24. This number is based on 25 men's scholarships at $\$ 30,000$ each, plus the possibility of savings on women's scholarships and the probable reduction in athletic support staff and equipment.

25. See Zimbalist, 2010a, for an elaboration on this analysis.

26. If two or more non-BCS teams satisfy the "automatic berth" provisions, then the team with the highest BCS rank will receive the automatic berth, and the remaining teams will be considered for an at-large selection (i.e., chosen at the discretion of the host bowl committee). As always, Notre Dame gets special treatment as an independent: it receives an automatic berth if it finishes in the top 8 in the BCS standings. In 2009, the BCS is working with another tweak in its selection formula. As explained on the BCS site, http://www.bcsfootball.org/cfb/story/5900394/ Bowl-Championship-Series-FAQ: "Each conference will be evaluated over a four-year period based on the [sic] three elements: the average rank of the highest ranked team; the average rank of all conference teams; and the number of teams in the top 25." As explained in the text, there are a number of factors that rigidify the status of automatic berth conferences. In the extremely improbable event that during the course of a four-year cycle one of the automatic berth conferences is threatened, the BCS conferences can always modify the procedures again, as it is the BCS conferences that govern the system.

27. BCS conferences actually earn additional revenue. Under BCS rules, BCS conferences are required to purchase $50 \%$ of the seats at BCS bowls, but they pay only $60 \%$ of each ticket's face value. Schools apparently sell discounted tickets to students, but sell full price tickets to alumni, to boosters and to other fans. Of course, for some matchups, such as the 2008-09 contest between Cincinnati and Virginia Tech, the BCS schools will have to sell most of their tickets at the discounted price and their revenue gain will be more modest.

28. Of course, a sixteen-team playoff, which is practiced in the FCS and Division III football, would generate even more excitement and revenue. One plausible selection process for an eightteam playoff would be to choose the conference champions from the FBS conferences which had the eight best records. Jim Delaney, the commissioner of the Big Ten conference, told the House Subcommittee on Commerce, Trade and Consumer Protection on December 7, 2005, that a playoff system would increase television rights fees by hundreds of millions of dollars. Darren Rovell (2008[AUQ1]) estimates that rights fee would go up 2.5 times initially, and even more after the Rose Bowl is collapsed into the mix. Cowen (2003) cites Neil Pilson who estimates that there would be a big boost in TV rights fees from a playoff structure. DeLoss Dodds, AD at the University of Texas, believes that a playoff system would be so popular that it would add at least an extra $\$ 1$ million in revenue for every team playing Division IA football. Others have offered similar estimates, see A. Zimbalist, 2010a.

29. This survey is available at www.knightcommission.org. College presidents have been historically loathe to address the need for athletic reform. The average tenure of a college president is around six years; building a coalition for reform takes a long time and risks incurring the wrath of the trustees, the local boosters, many alumni and students. Several college presidents who have been outspoken about the need to reform found themselves pushed out of office. Given that no effective reform has thwarted the commercial juggernaut of college sports in over a century and given the long list of pressing matters concerning college governance, it is simply not in a president's interest to concentrate on athletics.

30. Machen was previously president of the University of Utah, sensitizing him to the perspective of the nonequity conferences in the FBS. 


\section{Acknowledgments}

The author wishes to thank Amy Perko, Mary Jo Kane and Jeff Orleans for their comments on an earlier draft of this paper.

\section{References}

Barra, A. (2005). The Last Coach: A Life of Paul “Bear” Bryant. New York: W. W. Norton.

Bowl Championship Series, Bowl Championship Series FAQ, http://www.bcsfootball.org/ cfb/story/5900394/Bowl-Championship-Series-FAQ

Brown, G. "Refined Reporting Shines Brighter Light on Spending," The NCAA News, April 17, 2008.

Clotfelter, C. unpublished research, 2009.

Cowen, S. "BCS or Bust: Competitive and Economic Effects of the Bowl Championship Series On and Off the Field," Testimony before the U.S. Senate Committee on the Judiciary, October 29, 2003.

Frank, R. "Challenging the Myth: A Review of the Links Among College Athletic Success, Student Quality, and Donations," report prepared for the Knight Foundation Commission on Intercollegiate Athletics, May 2004.

Fulks, D. NCAA Revenues and Expenses of Division I Intercollegiate Athletic Programs Report, 2004-08. Indianapolis: NCAA, August 2009.

Humphreys, B., \& Mondello, M. (2007). Intercollegiate Athletic Success and Donations at NCAA Division I Institutions. Journal of Sport Management, 21(2).

Johnson, J., "The Suicide Season,” The Shreveport Times, September 4, 2008.

Litan, R., J. Orszag \& P. Orszag, "The Empirical Effects of Collegiate Athletics: An Interim Report," Sebago Associates for the NCAA, August 2003.

McDonald, B. “The 'Flutie Factor' Is Now Received Wisdom. But Is It Real?” Boston College Magazine, Spring 2003.

Orszag, J. \& P. Orszag, “The Empirical Effects of Collegiate Athletics: An Update," Compass for the NCAA, April 2005.

Orszag, J. \& M. Israel, "The Empirical Effects of Collegiate Athletics: An Update Based on 2004-07 Data," Compass Lexicon for the NCAA, February 2009.

NCAA, Gender Equity Report, 2005-06. October 2008.

Pope, D., \& Pope, J. (2009). The Impact of College Sports Success on the Quantity and Quality of Student Applications. Southern Economic Journal, 75(3).

Rhoads, T.A., \& Gerking, S. (2000). Educational Contributions, Academic Quality and Athletic Success. Contemporary Economic Policy, 18.

Rovell, D. College Football Playoffs: I'll Say They're Worth \$160 Million a Year, CNBC, January 9, 2008, http://www.cnbc.com/id/22570730.

Smith, M. (2009). "Must Win Situation,” Sports Business Journal, August, 24-30.

Stinson, J., \& Howard, D. (2007). Athletic Success and Private Giving to Athletic and Academic Programs at NCAA Institutions. Journal of Sport Management, 21(2).

Weiner, J. (2009). College Sports 101. Miami, Fla: Knight Foundation Commission on Intercollegiate Athletics. Downloaded [January 6, 2010] from www.knightcommission.org.

Wieberg, S. "Top assistants command big pay" USA Today November 10, 2009.

Zimbalist, A. (2001). Unpaid Professionals: Commercialism and Conflict in Big-Time College Sports. Princeton, N.J.: Princeton University Press.

Zimbalist, A., (2010a). "The BCS, Antitrust and Public Policy," The Antitrust Bulletin, Winter, 2010.

Zimbalist, A. (2010b). Circling the Bases: Essays on the Challenges and Prospects of the Sports Industry. Philadelphia: Temple University Press. 